\title{
Radial nerve palsy in humeral shaft fractures with internal fixation: analysis of management and outcome
}

\author{
T. R. Schwab ${ }^{1}$ (i) $\cdot$ P. F. Stillhard ${ }^{1} \cdot$ S. Schibli ${ }^{1}$ - M. Furrer ${ }^{1} \cdot$ C. Sommer ${ }^{1}$
}

Received: 14 September 2016 / Accepted: 21 February 2017 / Published online: 9 March 2017

(C) The Author(s) 2017. This article is published with open access at Springerlink.com

\begin{abstract}
Introduction The incidence of radial nerve injury after humeral shaft fractures is on average $11.8 \%$ (Shao et al., J Bone Jt Surg Br 87(12):1647-1652, 2005) representing the most common peripheral nerve injury associated with long bone fractures (Korompilias et al., Injury, 2013). The purpose of this study was to analyze our current policy and long-term outcome, regarding surgically treated humeral shaft fractures in combination with radial nerve palsy.

Materials and methods We retrospectively analyzed the data of patients with surgically treated humeral shaft fractures from 01/01/2003 to 28/02/2013. The analysis included fracture type, soft tissue injury regarding closed and open fractures, type of fixation, management, and outcome of radial nerve palsy.

Results A total of 151 humeral shaft fractures were fixed in our hospital. In $20(13 \%)$ cases, primary radial palsy was observed. Primary nerve exploration was performed in nine cases. Out of the 13 patients with follow-up, 10 showed a complete, 2 a partial, and 1 a minimal nerve recovery. Two of them underwent a revision procedure. Secondary radial nerve palsy occurred in $9(6 \%)$ patients postoperatively. In five patients, the radial nerve was not exposed during the initial surgery and, therefore, underwent revision with nerve exploration. In all 5, a potential cause for the palsy was found and corrected as far as possible with full recovery in 3 and minimal recovery in one patient. In four patients with exposure of the nerve during the initial
\end{abstract}

T. R. Schwab

tobias.r.schwab@gmail.com

1 Kantonsspital Graubünden, Loestrasse 170, 7000 Chur, Switzerland surgery, no revision was performed. All of these 4 showed a full recovery.

Conclusion Our study showed an overall rate of $19 \%$ radial nerve palsy in surgically treated humeral shaft fractures. Most of the primary palsies $(13 \%)$ recovered spontaneously, and therefore, nerve exploration was only exceptionally needed. The incidence of secondary palsy after surgery (6\%) was high and mainly seen after plate fixation. In these cases, we recommend early nerve exploration, to detect and treat potential curable neural lesions.

Keywords Humeral shaft fracture - Primary radial nerve palsy $\cdot$ Secondary radial nerve palsy $\cdot$ Internal fixation

\section{Introduction}

One of the most common reasons for peripheral nerve palsy is an injury of the radial nerve associated with a fracture of the humeral shaft [1-4]. Regarding the literature, the overall incidence of radial nerve palsy in patients with humeral shaft fracture is between 7 and $17 \%$ [3]. One can differ between primary or traumatic nerve injury and secondary or iatrogenic nerve injury following fracture fixation or manipulation $[3,5,6]$. Claessen et al. found an incidence of $7 \%$ for iatrogenic radial nerve palsy in patients with humeral shaft fractures, and data in the literature vary between 6 and 32\% [6-8].

Regarding treatment, no clear consensus exists regarding if and when the nerve should be explored surgically. Earlier studies have reported a high rate of spontaneous recovery in patients with primary nerve injury: A "wait and see" strategy seems to be widely accepted, and early nerve exploration is only recommended in special situations (e.g., open fractures) [1, 6, 9-11]. In contrast, the 
Table 1 "Primary radial nerve palsy" patients' characteristics and pattern of injury

\begin{tabular}{llll}
\hline Patients with primary radial nerve palsy $(n=20)$ & \\
\hline Age (years) & $40(17)$ & Fracture side left/right $(n)$ & $10 / 10$ \\
Sex: male/female $(n)$ & $11 / 9$ & AO 12-A/B/C $(n)$ & $7 / 8 / 5$ \\
BMI $\left(\mathrm{kg} \mathrm{m}^{-2}\right)$ & $24(5)$ & Open fractures $(n)$ & 5 \\
ASA $1 / 2 / 3(n)$ & $8 / 10 / 2$ & High-energy trauma $(n)$ & 8 \\
\hline
\end{tabular}

Data are expressed as mean (standard deviation) and numbers

$A O$ fracture classification by "Arbeitsgemeinschaft für Osteosynthesefragen", ASA American Society of Anesthesiologists classification of physical status, $B M I$ body mass index

Table 2 "Secondary radial nerve palsy" patients' characteristics and pattern of injury

\begin{tabular}{llll}
\hline \multicolumn{4}{l}{ Patients with secondary radial nerve palsy $(n=9)$} \\
\hline Age (years) & $45(20)$ & Fracture side left/right $(n)$ & $4 / 5$ \\
Sex: male/female $(n)$ & $100 / 0$ & AO 12-A/B/C $(n)$ & $4 / 2 / 3$ \\
BMI $\left(\mathrm{kg} \mathrm{m}^{-2}\right)$ & $25(6)$ & Open fractures $(n)$ & 1 \\
ASA 1/2/3 $(n)$ & $3 / 4 / 2$ & High-energy trauma $(n)$ & 4 \\
\hline
\end{tabular}

Data are expressed as mean (standard deviation) and numbers

$A O$ fracture classification by "Arbeitsgemeinschaft für Osteosynthesefragen", ASA American Society of Anesthesiologists classification of physical status, $B M I$ body mass index

opinions differ about necessity of early nerve exploration in patients suffering from secondary nerve palsy after the initial surgical fracture fixation. While some authors recommend early exploration [12], others advocate for a 4 or 6 month observation period [3, 5]. According to literature, there is no significant difference in overall recovery rate in primary radial nerve palsy $(88 \%)$ and secondary radial nerve palsy (93\%) [1].

Despite the lack of clear evidence for early exploration of secondary radial nerve palsy [6], we pursue this policy at our clinic. The purpose of this study was to retrospectively analyze treatment and long-term outcome of primary and secondary radial nerve palsy, observed in surgically treated humeral shaft fractures in a Swiss Level A Trauma Center within a 10-year period. In particular, we wanted to investigate whether a policy with early exploration for secondary radial nerve palsy, within a maximum of 2 weeks after trauma, is justified. In all patients with secondary palsy, which underwent early exploration, we found a potential cause for the palsy which we were able to treat surgically. We suppose that early exploration in secondary nerve palsy offers a chance for an earlier start of nerve rehabilitation and, therefore, leads to better outcomes.

\section{Materials and methods}

After the ethic committee approval (Kantonale Ethikkommission Zürich, 8090 Zurich, Switzerland, SNCTP000000337), all patients with surgically treated humeral shaft fractures treated at our institution during a 10-year period (01/01/2003-28/02/2013) were included. Patient charts, operation, and follow-up notes were retrospectively analyzed. Patients with pathologic humeral shaft fractures were excluded. Fracture fixation was done with plate osteosynthesis (POS) or intramedullary nailing (IM). The variables collected are shown in Tables 1, 2, 3, and 4 . The data were transferred into an anonymized chart using a standard spreadsheet software (Microsoft Excel).

Any documented sensory radial nerve palsy or a weakness of the wrist extensors or drop hand described in the medical records on admission or during hospitalization was defined as radial nerve palsy. For the fracture type, the AO classification was used, for grading of the soft tissue damage, the Anderson/Gustilo classification for open fractures and the Tscherne/Oestern classification for closed fractures were used [13-16]. Regarding trauma mechanism, we differentiated between high-energy and lower energy trauma. As high-energy trauma, we regarded high velocity car, motorbike, ski, snowboard, and paragliding accidents, as well as $\geq 2^{\circ}$ open fractures or $\geq \mathrm{G} 2$ soft tissue damage.

We analyzed patients in two independent groups: patients with primary or traumatic radial palsy presenting loss of radial nerve function at admission (group 1), and patients with secondary or iatrogenic radial palsy, presenting loss of radial nerve function after surgical fracture treatment (group 2). The documented recovery of radial nerve function during follow-up was assessed clinically including objective data such as electromyography and neurography (EMG/ENG) if present.

For patients' characteristics, the mean value with standard deviation was calculated, the follow-up is described as median with range. For statistical evaluation, the recovery rate was calculated as percentage.

\section{Results}

During the observed period, a total of 151 patients with a fracture of the humeral diaphysis underwent surgery with internal fracture fixation as a definitive treatment. 59\% received a plate osteosynthesis (POS) and $41 \%$ of the fractures were fixed by intramedullary nailing (IM). Regarding AO classification [16], among patients treated with POS, $44 \%$ fractures were classified as type C, $29 \%$ as type B and $27 \%$ as type A. In patients treated with IM, $8 \%$ were graded as type C, $29 \%$ as type B, and $63 \%$ as type A (Fig. 3). Patients' mean age was 49 (21) years. 
Table 3 Treatment and outcome group "primary radial nerve palsy"

\begin{tabular}{|c|c|c|c|c|c|c|c|c|}
\hline & Implant & Surgical approach & $\begin{array}{l}\text { Exploration } \\
\text { of radial } \\
\text { nerve }\end{array}$ & $\begin{array}{l}\text { Macroscopic } \\
\text { nerve lesion }\end{array}$ & Revision surgery & $\begin{array}{l}\text { Grade of nerve } \\
\text { injury }\end{array}$ & Clinical course & $\begin{array}{l}\text { Follow- } \\
\text { up } \\
\text { (months) }\end{array}$ \\
\hline $\mathrm{p} 1$ & LCP & Open dorsal & No & & No & Motor + sensory & Complete recovery & 32 \\
\hline $\mathrm{p} 2$ & LCP & Open dorsal & Primary & Contusion & No & Motor + sensory & - & Lost \\
\hline p3 & IM & $\begin{array}{l}\text { Percutaneous, ret- } \\
\text { rograde (initial } \\
\text { ex fix) }\end{array}$ & No & & No & Motor + sensory & Complete recovery & 17 \\
\hline $\mathrm{p} 4$ & $\mathrm{IM}$ & $\begin{array}{l}\text { Percutaneous ret- } \\
\text { rograde (initial } \\
\text { ex fix) }\end{array}$ & No & & No & Motor + sensory & - & Lost \\
\hline $\mathrm{p} 5$ & IM & $\begin{array}{l}\text { Percutaneous, } \\
\text { retrograde }\end{array}$ & No & & No & Sensory & $\begin{array}{l}\text { Complete recovery } \\
\text { after } 1.5 \text { months }\end{array}$ & 14 \\
\hline p6 & $\mathrm{IM}$ & $\begin{array}{l}\text { Percutaneous, } \\
\text { retrograde }\end{array}$ & No & & No & Motor + sensory & $\begin{array}{l}\text { Complete recovery } \\
\text { after } 3 \text { months }\end{array}$ & 3 \\
\hline $\mathrm{p} 7$ & LCP & Open dorsal & Primary & Contusion & Decompression & Motor + sensory & $\begin{array}{l}\text { Complete recovery } \\
\text { after } 3 \text { months }\end{array}$ & 3 \\
\hline $\mathrm{p} 8$ & $\mathrm{IM}$ & $\begin{array}{l}\text { Percutaneous, } \\
\text { retrograde }\end{array}$ & No & & No & Motor + sensory & Partial recovery & 6 \\
\hline p9 & LCP & Open dorsal & Primary & No & No & Motor + sensory & - & Lost \\
\hline p10 & LCP & Open dorsal & Primary & Contusion & No & Motor + sensory & - & Lost \\
\hline p11 & IM & $\begin{array}{l}\text { Percutaneous, } \\
\text { retrograde }\end{array}$ & No & & No & Motor + sensory & - & Lost \\
\hline p12 & LCP & $\begin{array}{l}\text { Open deltoido- } \\
\text { pectoral }\end{array}$ & No & - & No & Motor + sensory & Complete recovery & 20 \\
\hline p13 & LCP & $\begin{array}{l}\text { Open dorsal (ini- } \\
\text { tial ex fix) }\end{array}$ & Primary & $\begin{array}{l}90 \% \text { intact, } 10 \% \\
\text { ruptured }\end{array}$ & No & Motor + sensory & $\begin{array}{l}\text { Complete recovery } \\
\text { after } 16 \text { months }\end{array}$ & 31 \\
\hline p14 & LCP & $\begin{array}{l}\text { Open deltoido- } \\
\text { pectoral }\end{array}$ & Primary & No & No & Motor + sensory & - & Lost \\
\hline p15 & LCP & Open dorsal & Primary & No & No & Motor + sensory & $\begin{array}{l}\text { Complete recovery } \\
\text { after } 8 \text { months }\end{array}$ & 8 \\
\hline p16 & $\mathrm{IM}$ & $\begin{array}{l}\text { Percutaneous } \\
\text { retrograde }\end{array}$ & Secondary & Traumatic cut & $\begin{array}{l}\text { Yes, after } \\
7 \text { months nerve } \\
\text { graft tendon } \\
\text { transfer after } \\
16 \text { months }\end{array}$ & Motor + sensory & $\begin{array}{l}\text { Initial progres- } \\
\text { sion of Tinel's } \\
\text { response, then } \\
\text { stop }\end{array}$ & 16 \\
\hline p17 & $\mathrm{IM}$ & Dorsal distal & No & & No & Motor + sensory & $\begin{array}{l}\text { Complete recovery } \\
\text { after } 6 \text { months }\end{array}$ & 20 \\
\hline p18 & LCP & Open dorsal & Primary & No & No & Motor + sensory & $\begin{array}{l}\text { Complete recovery } \\
\text { after } 1 \text { months }\end{array}$ & 14 \\
\hline p19 & IM & $\begin{array}{l}\text { Percutaneous } \\
\text { retrograde }\end{array}$ & No & & No & Motor + sensory & - & Lost \\
\hline p20 & LCP & Open dorsal & Primary & No & No & Motor + sensory & Partial recovery & 13 \\
\hline
\end{tabular}

$I M$ intramedullary nailing, $L C P$ locking compression plate, $M I P O$ minimal invasive plate osteosynthesis

$13 \%$ (20 out of 151) of all patients showed primary radial nerve palsy. Table 1 shows patients' characteristics in this group. In $45 \%$ ( 9 out of 20), all of them patients with POS, an early exploration of the radial nerve was performed during the initial surgery. In one patient with a closed transverse fracture after high-energy direct trauma (IM), a secondary nerve exploration was performed during revision surgery 7-month post-trauma and a traumatic cut of the radial nerve was found at the fracture level. In
$50 \%$ (10 out of 20 ), there was no nerve exploration at all (Fig. 4; Table 3).

In $44 \%$ (4 out of 9) with primary radial nerve palsy and the initial exploration, minor nerve injuries such as contusions or superficial damage were found. In one patient, the surgeon decided to perform decompression, because the radial nerve seemed to be entrapped by tight soft tissue structures (intermuscular septum) in addition 
Table 4 Treatment and outcome group "secondary radial nerve palsy"

\begin{tabular}{|c|c|c|c|c|c|c|c|c|}
\hline & Implant & $\begin{array}{l}\text { Initial surgical } \\
\text { approach (1.Op) }\end{array}$ & $\begin{array}{l}\text { Exploration of } \\
\text { radial nerve }\end{array}$ & $\begin{array}{l}\text { Macroscopic } \\
\text { nerve lesion }\end{array}$ & Revision surgery & $\begin{array}{l}\text { Grade of nerve } \\
\text { injury }\end{array}$ & Clinical course & $\begin{array}{l}\text { Follow- } \\
\text { up } \\
\text { (months) }\end{array}$ \\
\hline s1 & LCP & $\begin{array}{l}\text { MIPO, delta-split, } \\
\text { open distally } \\
\text { (no primary } \\
\text { nerve explora- } \\
\text { tion) }\end{array}$ & Secondary & $\begin{array}{l}\text { Contusion, } \\
\text { scratched, irrita- } \\
\text { tion by plate }\end{array}$ & $\begin{array}{l}\text { Day } 6 \text { postop.: } \\
\text { decompression }\end{array}$ & Motor + sensory & $\begin{array}{l}\text { Complete } \\
\text { recovery after } \\
11 \text { months }\end{array}$ & 14 \\
\hline $\mathrm{s} 2$ & Ex fix & Percutaneous & $\begin{array}{l}\text { Secondary (dur- } \\
\text { ing change from } \\
\text { ex fix to plate) }\end{array}$ & $\begin{array}{l}10 \% \text { lacerated by } \\
\text { ex.-fix. pin }\end{array}$ & & Motor + sensory & $\begin{array}{l}\text { Complete } \\
\text { recovery after } \\
12 \text { months }\end{array}$ & 12 \\
\hline s3 & LCP & Open, dorsal & Primary & No & & Motor + sensory & $\begin{array}{l}\text { Complete recov- } \\
\text { ery (unclear } \\
\text { when) }\end{array}$ & 41 \\
\hline s4 & LCP & $\begin{array}{l}\text { MIPO, delta-split, } \\
\text { distally open }\end{array}$ & Primary & No & & Motor + sensory & $\begin{array}{l}\text { complete } \\
\text { recovery after } \\
12 \text { months }\end{array}$ & 12 \\
\hline s5 & LCP & $\begin{array}{l}\text { MIPO, delta-split, } \\
\text { distally open }\end{array}$ & Primary & $\begin{array}{l}\text { nerve trapped } \\
\text { under plate, } \\
\text { immediate } \\
\text { correction, } \\
\text { contusion }\end{array}$ & & Motor + sensory & - & Lost \\
\hline s6 & $\mathrm{IM}$ & $\begin{array}{l}\text { Percutaneous } \\
\text { antegrade }\end{array}$ & Secondary & $\begin{array}{l}\text { Complete transec- } \\
\text { tion by distal } \\
\text { locking bolt }\end{array}$ & $\begin{array}{l}\text { Day } 6 \text { postop.: } \\
\text { exploration, } \\
\text { day } 13 \text { postop.: } \\
70 \mathrm{~mm} \text { nerve } \\
\text { graft }\end{array}$ & Motor + sensory & $\begin{array}{l}\text { No recovery after } \\
1.5 \text { year } \rightarrow \text { ten- } \\
\text { don transfer }\end{array}$ & 18 \\
\hline s7 & LCP & $\begin{array}{l}\text { Open distally, } \\
\text { delta-split } \\
\text { proximal }\end{array}$ & Secondary & $\begin{array}{l}\text { Nerve under } \\
\text { plate, contusion }\end{array}$ & $\begin{array}{l}\text { Day } 5 \text { postop: } \\
\text { Revision }\end{array}$ & Motor + sensory & $\begin{array}{l}\text { Partial recovery, } \\
\text { decreased } \\
\text { strength and } \\
\text { persisting sen- } \\
\text { satory deficit }\end{array}$ & 24 \\
\hline s8 & LCP & $\begin{array}{l}\text { Open distal dor- } \\
\text { sal, local nerve } \\
\text { exposure prox. } \\
\text { the fracture }\end{array}$ & Primary & No & & Sensory & $\begin{array}{l}\text { Complete } \\
\text { recovery after } \\
7 \text { months }\end{array}$ & 7 \\
\hline s9 & LCP & Open, dorsal & Secondary & $\begin{array}{l}\text { Contusion by } \\
\text { bone fragment }\end{array}$ & $\begin{array}{l}\text { Day } 9 \text { postop.: } \\
\text { new plate fixa- } \\
\text { tion, removal of } \\
\text { bone fragment }\end{array}$ & Sensory & $\begin{array}{l}\text { Complete recov- } \\
\text { ery }\end{array}$ & 3 \\
\hline
\end{tabular}

$I M$ intramedullary nailing, $L C P$ locking compression plate, $M I P O$ minimal invasive plate osteosynthesis

to the damage by the fracture itself. In $56 \%$ (5 out of 9 ), no macroscopic injury was found.

Median follow-up in this group was 14 (3-32) months. $35 \%$ (7 out of 20) were lost during the follow-up due to foreign domicile. Within the group of patients with primary palsy and follow-up, 77\% (10 out of 13) showed a complete and $15 \%$ (2 out of 13 ) partial recovery of radial nerve function without further surgical interventions (Fig. 5). The one patient suffering from a traumatic cut underwent several revision procedures. Unfortunately, an initial progression of the Tinel's response from the fracture localization $20 \mathrm{~cm}$ above the elbow joint till $8 \mathrm{~cm}$ above elbow was misinterpreted as nerve recovery. As there was no further progression of the Tinel's response and no functional nerve recovery, 7-month posttrauma, the revision was performed and a nerve graft was implanted. Finally, without satisfying recovery of the nerve function after more than 1 year, a tendon transfer operation was carried out.

$6 \%$ (9 out of 151) of all patients suffered from secondary radial nerve palsy. Table 2 shows patients' characteristics in this group. In $78 \%$ (7 out of 9), the radial nerve palsy occurred after POS, in $11 \%$ (1 out of 9) after IM and in $11 \%$ ( 1 out of 9 ) after temporary fracture fixation with an external fixator. In $44 \%$ (4 out of 9) of these patients with secondary nerve palsy, radial nerve exposure was performed at the time of the initial surgery due 


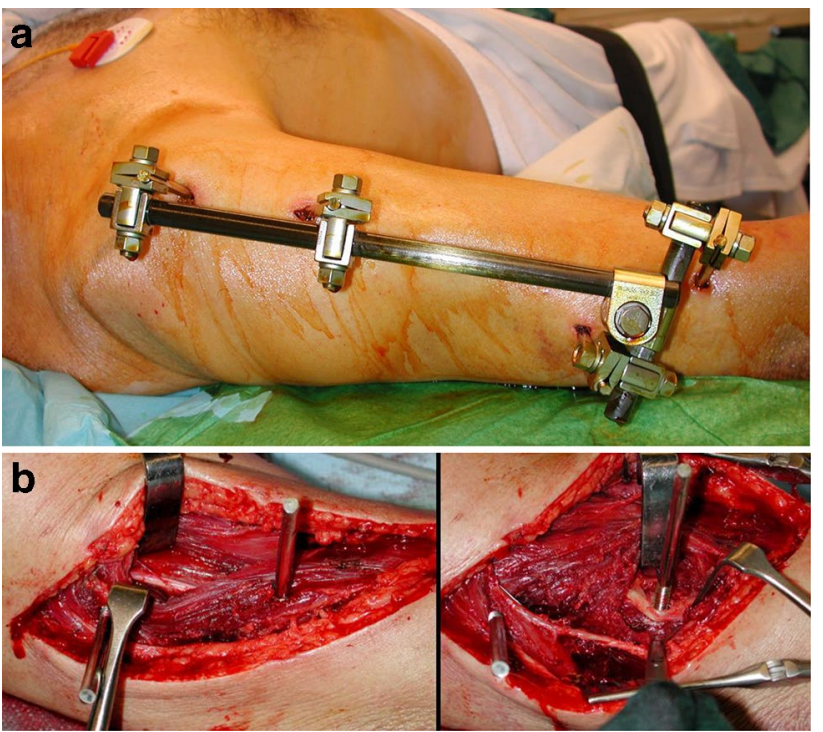

Fig. 1 a 62 years, car accident, secondary nerve palsy after application of an external fixator, b 62 years, distal pin runs through brachioradial muscle winding up the radial nerve and destroyed $10 \%$ of its circumference

to the chosen approach for fracture fixation $(2 \times$ dorsal ORIF, ${ }^{1} 2 \times$ anterolateral $\mathrm{MIPO}^{2}$ ). In all these cases, an intact nerve was initially observed, and therefore, no further revision procedure was performed despite the fact that secondary palsy occurred. In the remaining 56\% (5 out of 9), in which the radial nerve was not exposed during the initial surgery, a revision surgery was performed within a maximum of 9 days after the initial intervention (Fig. 6; Table 4).

In all patients who underwent surgical revision, macroscopic nerve damage was found: damage by a pin of the external fixator (Fig. 1a, b), compression by a bone fragment (Fig. 2), entrapment between plate and bone, irritation or displacement by the plate, and damage by a distal locking bolt of the intramedullary nail were among the causes of these nerve injuries.

During revision procedures, the probable cause for the secondary palsy could be corrected: the bone fragment was removed (Fig. 2), the compressed nerves were released, and the plates repositioned and the transected nerve fixed by an early neural graft.

Median follow-up in this group was 13 (3-41) months. $11 \%$ ( 1 out of 9) were lost to follow-up. $75 \%$ (6 out of 8 ) showed a complete recovery of nerve function (Fig. 5). The one patient with the nerve compressed under the plate only showed partial recovery of nerve function, despite releasing

\footnotetext{
${ }^{1}$ ORIF: open reduction, internal fixation.

${ }^{2}$ MIPO: minimal invasive plate osteosynthesis.
}

the nerve within only 5 days after the initial surgery. The one patient with palsy after IM presented a major nerve damage of approximately $7 \mathrm{~cm}$, probably due to winding up the nerve with the locking bolt. Despite nerve graft implantation and several revision procedures, a tendon transfer had to be performed ultimately.

Regarding nerve recovery depending on fixation technique, primary palsy treated with POS showed an $86 \%$ (6 out of 7) complete recovery rate. Primary palsy treated with IM showed a $67 \%$ (4 out of 6 ) complete recovery rate. Secondary palsy definitively treated with POS showed complete recovery in $86 \%$ ( 6 out of 7 ) of the cases and the one patient with IM did not show any recovery. Data are visualized in Fig. 7. Thirty-five percent (7 out of 20) were lost to follow-up.

Regarding trauma energy in patients with primary radial nerve palsy, $40 \%$ (8 out of 20 ) suffered from high-energy trauma. Out of these, $60 \%$ (3 out of 5) showed complete recovery. Without high-energy trauma, $88 \%$ (7 out of 8 ) recovered completely (Fig. 8). Thirty-five percent ( 7 out of 20) were lost to follow-up.

Regarding patients with secondary nerve palsy, $44 \%$ (4 out of 9) suffered from high-energy trauma, from which $50 \%$ (2 out of 4) recovered completely. Without highenergy trauma, $100 \%$ (4 out of 4) of patients showed a complete recovery (Fig. 8). Eleven percent (1 out of 9) were lost to follow-up.

\section{Discussion}

Regarding primary or traumatic radial nerve palsy associated with humeral shaft fractures, our study showed a high rate of spontaneous complete recovery of nerve function (77\%), correlating well with the literature $[1,10,11,17]$. Early exploration of the radial nerve in primary traumatic palsy does not seem to be necessary, especially in closed fractures, where a primary serious nerve damage requiring surgical repair is very rare. In our collective, this was true for only one patient (see below). Out of nine patients who underwent early exploration, only in one case, a decompression of the nerve, at the level where it passes the intermuscular septum, seemed to be indicated and was performed. The other cases with early exploration only showed minor to no damage and no possibility of surgical treatment. Out of the eight patients with follow-up after primary palsy without nerve exploration at the time of surgery, six showed a complete and one patient a partial recovery. Only in one case after high-energy direct trauma with a transverse fracture, a complete transection of the nerve at fracture level was detected 7-month post-trauma during revision surgery while failing to regain nerve function. Despite 
Fig. 219 years, secondary nerve palsy after POS; bony fragment (blue arrow) sticking in a perineural small artery, adjacent to the radial nerve (yellow dotted line)
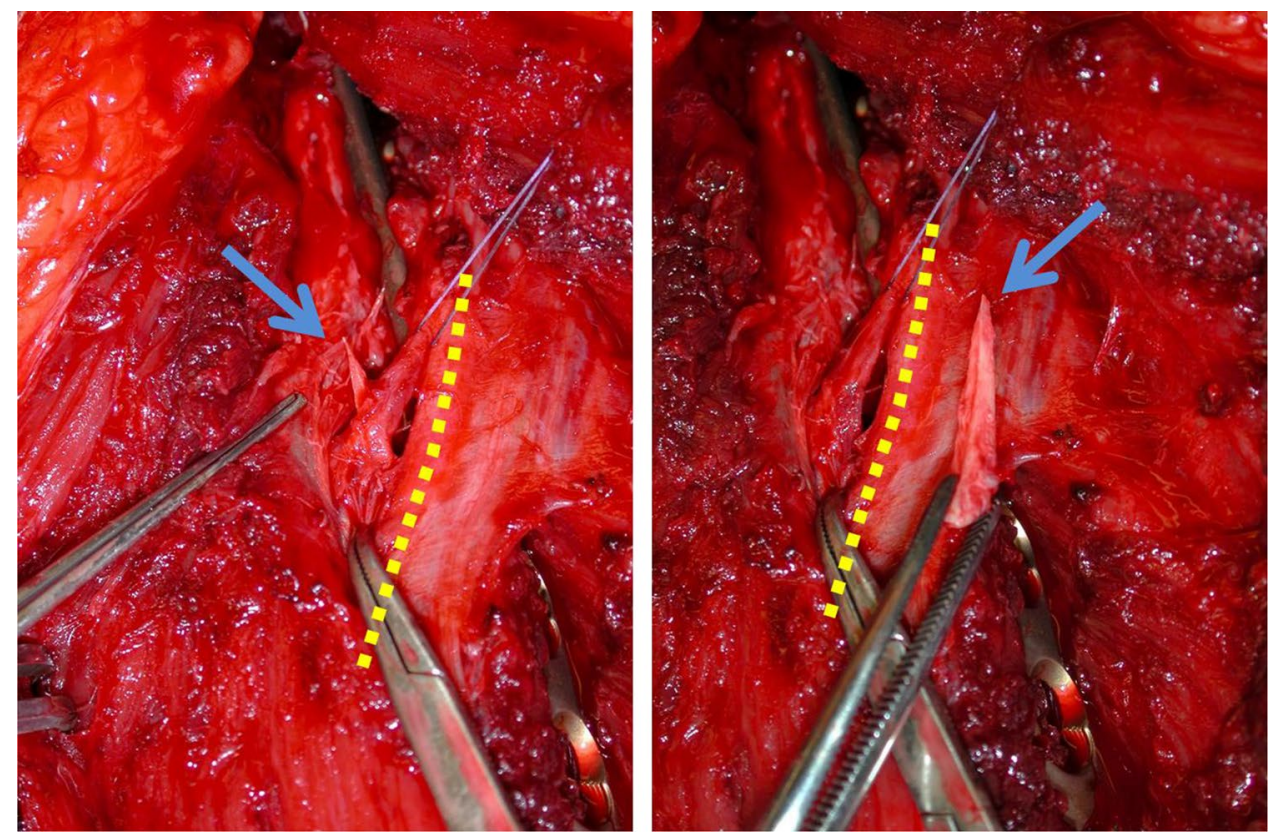

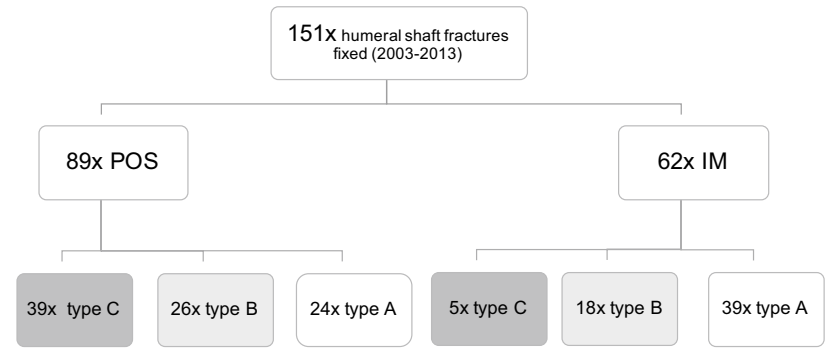

Fig. 3 Distribution of surgically treated fractures regarding AO fracture classification [16]. Data are expressed as numbers and fracture type (AO 12-x); $A O$ fracture classification by "Arbeitsgemeinschaft für Osteosynthesefragen", $I M$ intramedullary nailing, $P O S$ plate osteosynthesis

nerve grafting, major motoric deficits remained requiring a tendon transfer later on.

The low risk of primary neural damage requiring surgical repair (8\%) does not justify an early nerve exploration in all the cases with nerve palsy. It could be a viable option in certain cases such as open fractures or cases with high-energy trauma $[18,19]$. Furthermore, a primary nerve palsy should not influence the decision between conservative or operative treatment and the choice of implant being either a plate or a nail [3].

Several limitations regarding our conclusions have to be pointed out: with our small case load and the large number of patients lost to follow-up (35\%), further statistical analysis with scientific validity is not reasonable, but our observations equate conclusions drawn from earlier studies [1].

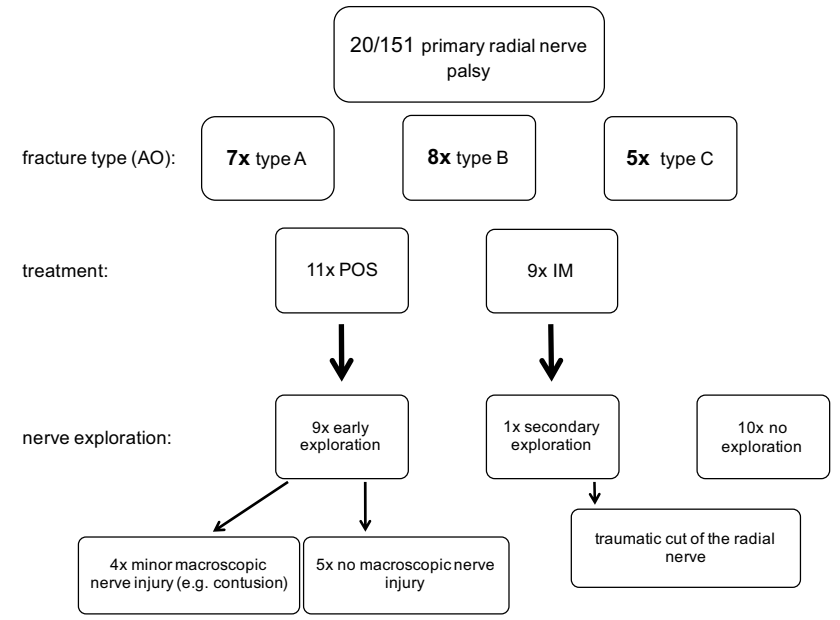

Fig. 4 Treatment and nerve exploration in primary radial nerve palsy patients. Data are expressed as numbers; $A O$ fracture classification by "Arbeitsgemeinschaft für Osteosynthesefragen", IM intramedullary nailing, POS plate osteosynthesis

Claessen et al. found radial nerve palsy in humeral shaft fractures significantly associated with high-energy trauma, open fractures, as well as surgical approach [8]. Considering the low number of patients in these subgroups, differences in outcome comparing osteosynthesis methods and trauma energy in our study (Figs. 7, 8) have to be interpreted with caution and no definitive conclusions can be drawn from these observations.

Dealing with secondary radial nerve palsy detected after an surgical fracture fixation, we believe that an exploration of the radial nerve, if not already done during the first 


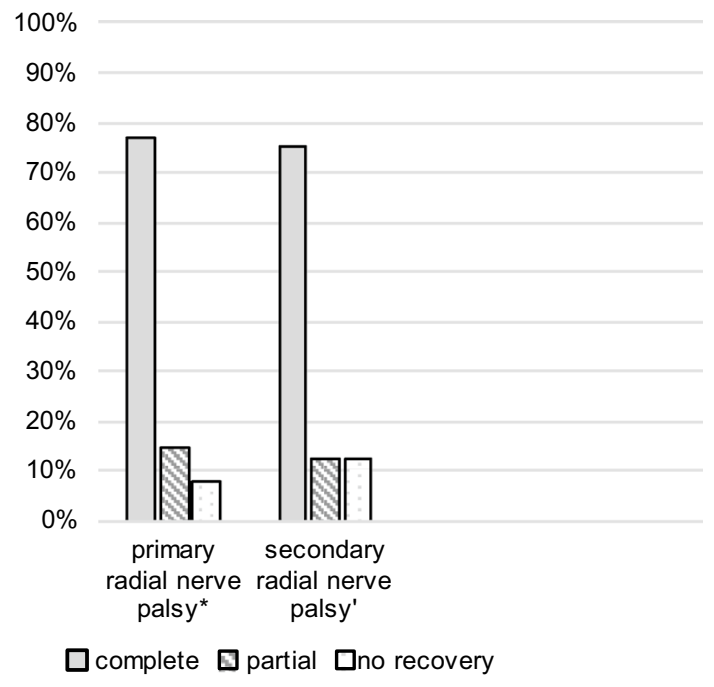

Fig. 5 Recovery rate of nerve function in primary and secondary radial nerve palsy. Data are expressed as percentage: (asterisk) $n=13$, median follow-up 14 (3-32) months (7 patients lost to follow-up); (single quote) $n=8$, median follow-up 13 (3-41) months (1 patient lost to follow-up)
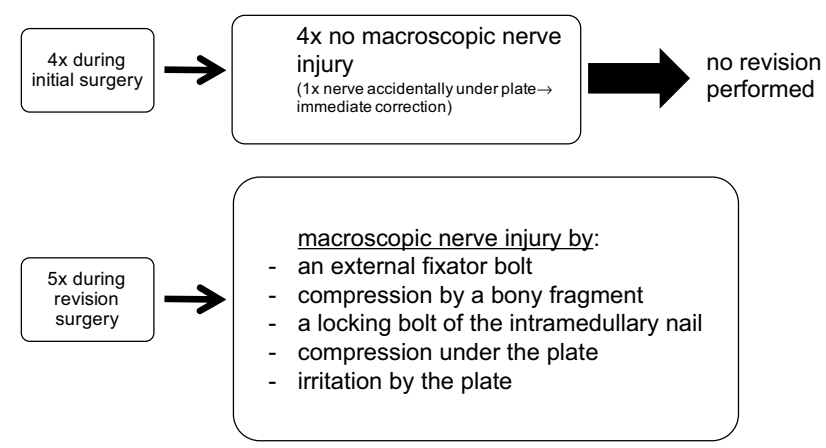

Fig. 6 Radial nerve exploration and findings in secondary radial nerve palsy surgery, is obligatory and should be performed shortly after the first operation: With a $6 \%$ rate (9 patients out of 151) of postoperative or iatrogenic radial nerve injury, we had a slightly lower complication rate than average [4, 6, 8]. The impairment in everyday life as well as the psychological strain for patients suffering from a radial nerve palsy are severe and should be avoided if possible [18, 20]. This implies an explicit patient information preoperatively.

In four patients with secondary palsy, the radial nerve was initially explored during definitive fracture fixation due to the surgical approach (posterior or anterolateral distally, Table 4). As to be expected, the nerve was found to be intact. In these four cases, no early revision was performed, and in the three patients with follow-up, a full recovery was observed. There are several risks and reasons for a secondary radial palsy during fracture fixation: even light tension to the nerve during exploration might cause neurapraxia. Another potential source for injury is the positioning of the patient before and during surgery. Under general anesthesia, the loss of consciousness along with muscle tone might lead to accidental and excessive movement at the fracture site. Similar traction damage can occur because of excessive indirect fracture manipulation during nailing. A strong tension to the surrounding radial nerve or an entrapment between bone fragments can be the consequence [4-6, 21]. Therefore, a temporary fracture immobilization, e.g., with a cast and attention during anesthetic induction and patient positioning, of both the surgeon and the support personal have to be guaranteed. Great caution should be taken during the approach and the fracture reduction [8]. In the critical region especially from the middle to the distal humeral shaft, where the radial nerve transverses the intermuscular septum, special retraction devices such as Hohmann retractors are dangerous. Their use should be avoided.
Fig. 7 Recovery rate of nerve function in consideration of the fracture treatment. Data are expressed as percentage: (asterisk) $n=7$ (7 patients lost to follow-up); $n=6 ;$ (dagger) $n=7$ ( 1 patient lost to followup); (double dagger) $n=1 ; I M$ intramedullary nailing, $P O S$ plate osteosynthesis

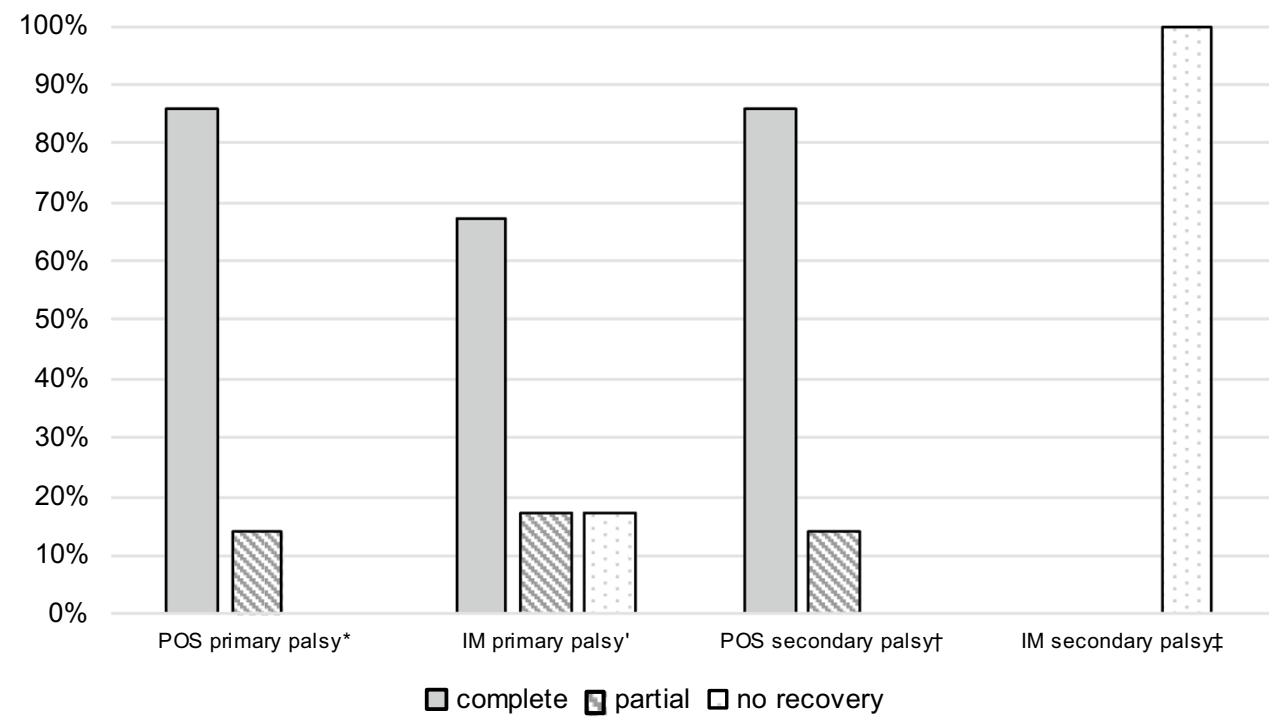


Fig. 8 Recovery rate of nerve function in consideration of the trauma energy. Data are expressed as percentage: (asterisk) $n=5$ (3 patients lost to follow-up); $n=8$ (4 patients lost to follow-up); (dagger) $n=4$; (double dagger) $n=4$ (1 patient lost to follow-up)

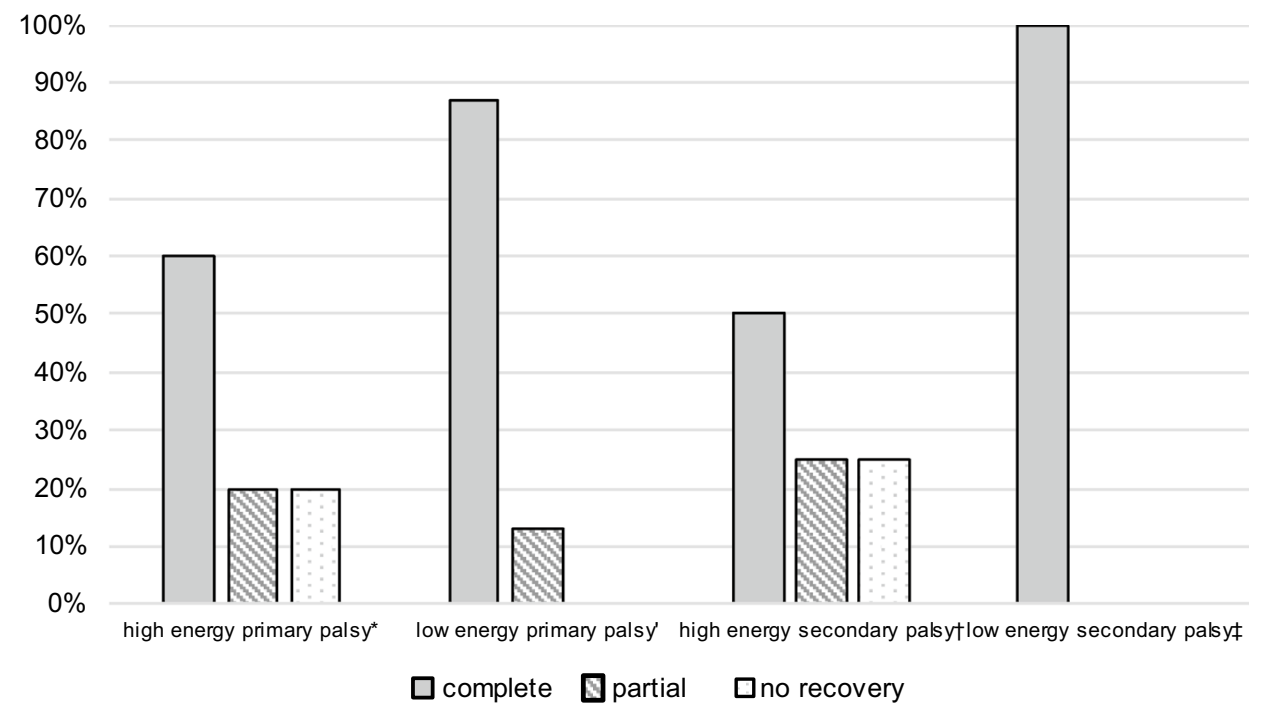

In all the five patients with secondary radial palsy after fracture fixation without exploration of the radial nerve, we went for early revision with exploration of the radial nerve (Fig. 6; Table 4). In all these patients, macroscopic nerve damage was found and an appropriate treatment was applied: In one case, a sharp spiky bone fragment traversing the radial nerve was removed (Fig. 2). In three cases after partially percutaneous anterolateral plate fixation, the entrapped or compressed nerves were released and two plates had to be newly positioned. In one case, after antegrade nail fixation, a nerve was found to be transected at the level of the distal locking bolts, most likely caused by the percutaneous drilling maneuver. This nerve was repaired by an early neural graft, unfortunately without great success. Because of this experience, we believe that our approach with early nerve exploration for secondary radial nerve palsy is reasonable. Due to scar tissue, a revision surgery with a maximum of 10-14 days after the initial surgery seems to be more easy than 3-4 months later as it is proposed by other authors $[4,6$, 22 ]. With a total recovery rate of $75 \%$ in secondary nerve palsy, we observed a similar rate comparing it to primary radial nerve palsy $(77 \%)$. It remains questionable whether the recovery rate would have been the same without early exploration in the five patients mentioned above. It can be assumed that rehabilitation would have been postponed and a later on secondary exploration would have been necessary.

Since all patients with secondary nerve palsy underwent nerve exploration within 9 days after trauma, a statement about the outcome without early exploration cannot be made.

In conclusion, we think that a "wait and observe" strategy for a potentially compressed or damaged radial nerve is wrong. We recommend early nerve exploration in patients with secondary radial nerve palsy in which the nerve had not been exposed during the initial surgery.

\section{Compliance with ethical standards}

Our study has been approved by the ethics committee "Kantonale Ethikkommission Zürich", 8090 Zürich, Switzerland (SNCTP000000337, KEK-ZH 2014-0116). We went for the ethics committee's approval before processing and analyzing our data. Under the legal framework and according to the ethics committee's confirmation, a written consent was not necessary for our study with its retrospective design and anonymized data and thus not requested from our patients.

Conflict of interest The authors Tobias Schwab, Philipp Stillhard, Silvia Schibli, Markus Furrer, and Christoph Sommer declare that they have no conflict of interests.

Open Access This article is distributed under the terms of the Creative Commons Attribution 4.0 International License (http:// creativecommons.org/licenses/by/4.0/), which permits unrestricted use, distribution, and reproduction in any medium, provided you give appropriate credit to the original author(s) and the source, provide a link to the Creative Commons license, and indicate if changes were made.

\section{References}

1. Korompilias AV, Lykissas MG, Kostas-Agnantis IP, Vekris MD, Soucacos PN, Beris AE. Approach to radial nerve palsy caused by humerus shaft fracture: is primary exploration necessary? Injury. 2013. doi:10.1016/j.injury.2013.01.004.

2. Shao YC, Harwood P, Grotz MR, Limb D, Giannoudis PV. Radial nerve palsy associated with fractures of the shaft of the humerus: a systematic review. J Bone Jt Surg Br. 2005;87(12):1647-52. doi:10.1302/0301-620X.87B12.16132.

3. Liu GY, Zhang CY, Wu HW. Comparison of initial nonoperative and operative management of radial nerve palsy associated with acute humeral shaft fractures. Orthopedics. 2012;35(8):702-8. doi:10.3928/01477447-20120725-10. 
4. Wang X, Zhang P, Zhou Y, Zhu C. Secondary radial nerve palsy after internal fixation of humeral shaft fractures. Eur Orthop Surg Traumatol Orthop Traumatol. 2014;24(3):331-3. doi:10.1007/ s00590-013-1197-y.

5. Wang JP, Shen WJ, Chen WM, Huang CK, Shen YS, Chen $\mathrm{TH}$. Iatrogenic radial nerve palsy after operative management of humeral shaft fractures. J Trauma. 2009;66(3):800-3. doi:10.1097/TA.0b013e31816142cf.

6. Hak DJ. Radial nerve palsy associated with humeral shaft fractures. Orthopedics. 2009;32(2):111.

7. Bumbasirevic M, Lesic A, Bumbasirevic V, Cobeljic G, Milosevic I, Atkinson HD. The management of humeral shaft fractures with associated radial nerve palsy: a review of 117 cases. Arch Orthop Trauma Surg. 2010;130(4):519-22. doi:10.1007/ s00402-009-0951-4.

8. Claessen FM, Peters RM, Verbeek DO, Helfet DL, Ring D (2015) Factors associated with radial nerve palsy after operative treatment of diaphyseal humeral shaft fractures. J Shoulder Elb Surg Am Shoulder Elb Surg [et al] 24 (11):e307-11. doi:10.1016/j.jse.2015.07.012.

9. Bishop J, Ring D. Management of radial nerve palsy associated with humeral shaft fracture: a decision analysis model. J Hand Surg [Am]. 2009;34(6):991-6.e991. doi:10.1016/j. jhsa.2008.12.029.

10. Grassmann JP, Jungbluth P, Bullermann L, Hakimi M, Gehrmann SV, Thelen S, Betsch M, Windolf J, Wild M. Radial nerve palsy associated with humeral shaft fractures-early exploration or expectant procedure? An analysis concerning current strategies of treatment. Zeitschrift fur Orthopadie Unfallchirurgie. 2010;148(6):691-6. doi:10.1055/s-0030-1250107.

11. Grass G, Kabir K, Ohse J, Rangger C, Besch L, Mathiak G. Primary exploration of radial nerve is not required for radial nerve palsy while treating humerus shaft fractures with unreamed humerus nails (UHN). Open Orthop J. 2011;5:319-23. doi:10.21 74/1874325001105010319.

12. Kwasny O, Maier R, Kutscha-Lissberg F, Scharf W. Treatment procedure in humeral shaft fractures with primary or secondary radial nerve damage. Unfallchirurgie. 1992;18(3):168-73.
13. Gustilo RB, Mendoza RM, Williams DN. Problems in the management of type III (severe) open fractures: a new classification of type III open fractures. J Trauma. 1984;24(8):742-6.

14. Gustilo RB, Anderson JT. Prevention of infection in the treatment of one thousand and twenty-five open fractures of long bones: retrospective and prospective analyses. J Bone Jt Surg Am. 1976;58(4):453-8.

15. Tscherne $\mathrm{H}$, Oestern HJ. A new classification of soft-tissue damage in open and closed fractures (author's transl). Unfallheilkunde. 1982;85(3):111-5.

16. Müller ME, Koch P, Nazarian S, Schatzker J. The comprehensive classification of fractures of long bones. Berlin: Springer; 1990

17. Pailhe R, Mesquida V, Rubens-Duval B, Saragaglia D (2015) Plate osteosynthesis of humeral diaphyseal fractures associated with radial palsy: twenty cases. Int Orthop. doi:10.1007/ s00264-015-2745-3.

18. Ricci FP, Barbosa RI, Elui VM, Barbieri CH, Mazzer N, Fonseca Mde C (2015) Radial nerve injury associated with humeral shaft fracture: a retrospective study. Acta Ortop Bras. 23 (1):19-21. doi:10.1590/1413-78522015230100823.

19. Noaman H, Khalifa AR, El-Deen MA, Shiha A. Early surgical exploration of radial nerve injury associated with fracture shaft humerus. Microsurgery. 2008;28(8):635-42. doi:10.1002/ micr.20542.

20. Kozin SH. Tendon transfers for radial and median nerve palsies. J Hand Ther Off J Am Soc Hand Ther. 2005;18(2):208-15. doi:10.1197/j.jht.2005.02.003.

21. Holstein A, Lewis GM. Fractures of the humerus with radialnerve paralysis. J Bone Jt Surg Am. 1963;45:1382-8.

22. Antoniadis G, Kretschmer T, Pedro MT, Konig RW, Heinen CP, Richter HP. Iatrogenic nerve injuries: prevalence, diagnosis and treatment. Dtsch Arztebl Int. 2014;111(16):273-9. doi:10.3238/ arztebl.2014.0273. 